\title{
Evaluation of the antibacterial activity of Artemisia ludoviciana subsp. Mexican against three enterobacteria
}

\section{Evaluación de la actividad antibacteriana de Artemisia ludoviciana subsp. mexicana contra tres enterobacterias}

\author{
HERNÁNDEZ-MORALES, Alejandro†**, AVILA-PADRÓN, Francisco Javier, CARRANZA-
} ÁLVAREZ, Candy and MALDONADO-MIRANDA, Juan José

Unidad Académica Multidisciplinaria Zona Huasteca. Universidad Autónoma de San Luis Potosí. Romualdo del Campo 501, Fraccionamiento Rafael Curiel, Ciudad Valles S.L.P. Ciudad Valles San Luis Potosí, México. CP 79060

ID $1^{\text {st }}$ Author: Alejandro, Hernández-Morales / ORC ID: 0000-0002-0412-4946, Researcher ID Thomson: P-8441-2014, CVU CONACYT ID: 101590

ID $1^{\text {st }}$ Coauthor: Francisco Javier, Ávila-Padrón

ID $2^{\text {nd }}$ Coauthor: Candy, Carranza-Álvarez / ORC ID: 0000-0002-6456-3035, CVU CONACYT ID: 43169

ID $3^{\text {rd }}$ Coauthor: Juan José, Maldonado-Miranda / ORC ID: 0000-0003-2905-9914, CVU CONACYT ID: 390832

DOI: $10.35429 / J N A S .2019 .19 .6 .1 .12$

Received June 21, 2019; Accepted December 30, 2019

Abstract

Fractionated extraction of the leaves of Artemisia ludoviciana subsp. mexicana was performed, using hexane, dichloromethane and methanol, to obtain compounds of different polarity. Essential oils, aqueous decoction and hydroalcoholic extract were also obtained. Phytochemical profile was determined for each extract based on coloration and precipitation tests. Extracts were evaluated against three enterobacteria using the plate microdilution method. Chemical analysis revealed that dichloromethane fraction has a greater variety of compounds than hexane and methanolic fractions. The content of compounds of dichloromethane fraction correlates with the highest antimicrobial activity observed, suggesting that metabolites responsible for antimicrobial effect are intermediate polarity. Regarding extracts, ethanolic extract exerts a better effect than the decoction, while the essential oil shows the same antibacterial effect at low concentrations. Results demonstrate that $A$. ludoviciana subsp. mexicana has a great variety of compounds, which, according to their nature, can be eluted with solvents of different polarity. These compounds contribute to the antibacterial effect attributed to this plant.

Medicinal plants, Extract, Antimicrobial

\section{Resumen}

Se realizó la extracción fraccionada de las hojas de Artemisia ludoviciana subsp. mexicana, utilizando hexano, diclorometano y metanol para obtener compuestos de distinta polaridad. Además, se obtuvieron los aceites esenciales, una decocción acuosa y un extracto hidroalcohólico. En cada extracto obtenido, se determinó el perfil fitoquímico mediante pruebas de coloración y precipitación. Cada extracto fue evaluado contra tres enterobacterias utilizando el método de microdilución en placa. Los resultados obtenidos del análisis químico revelan que la fracción diclorometánica presenta mayor variedad de compuestos en comparación con las fracciones hexánica y metanólica. El contenido de compuestos de la fracción diclorometánica correlaciona con la mayor actividad antimicrobiana observada, sugiriendo que los metabolitos responsables del efecto antimicrobiano son de polaridad intermedia. En lo que respecta a los extractos, el etanólico ejerce mejor efecto que la decocción, mientras que el aceite esencial ejerce el mismo efecto antibacteriano a bajas concentraciones. Estos resultados demuestran que $A$. ludoviciana subsp. mexicana posee gran variedad de compuestos, los cuales, de acuerdo a su naturaleza, pueden ser eluídos con solventes de distinta polaridad. Estos compuestos contribuyen al efecto antibacteriano atribuido a esta planta.

Plantas medicinales, Extractos, Antimicrobiano

Citation: HERNÁNDEZ-MORALES, Alejandro, AVILA-PADRÓN, Francisco Javier, CARRANZA-ÁLVAREZ, Candy and MALDONADO-MIRANDA, Juan José. Evaluation of the antibacterial activity of Artemisia ludoviciana subsp. Mexican against three enterobacteria. Journal of Natural and Agricultural Sciences. 2019, 6-19: 1-12

\footnotetext{
*Correspondence to the Author (email: alejandro.hernandez@uaslp.mx)
}

$\dagger$ Researcher contributing first author. 


\section{Introduction}

It is currently estimated that about $80 \%$ of the population in developing countries depend on the use of medicinal plants to meet primary health needs (Caniato and Puricelli, 2003; Diéguez et al., 2004). The use of plants is due to the presence of substances with pharmacological activity (Dixon, 1986).

In Mexico there is a wide variety of plants, which have been used for medicinal purposes and support traditional medicine. In this sense, it is estimated that $85 \%$ of the population resorts to medicinal plants, which indicates their cultural roots (Sarukhán, 1995).

In San Luis Potosí, the use of medicinal plants is very common in the communities belonging to the Huasteca Potosina, a region of lush vegetation that comprises 26 of the 58 municipalities that make up the state. One of the municipalities where floristic and ethnobotanical studies have been conducted is Aquismón, in which a large number of medicinal plants are located. The use of 73 plants, belonging to 37 families, has been reported, with the Asteracea family plants being the most used in the region (Alonso-Castro et al., 2012).

The plants are used alone or in combination with others for the treatment of different diseases, according to the traditions reported in the region by traditional doctors, sorcerers and shamans. Among these plants the use of Artemisia ludoviciana subsp. Mexican, commonly known as estafiate (Alonso-Castro et al., 2012). The leaves of the plant are used in infusion for the treatment of stomach pain, diarrhea and intestinal parasites (Alonso-Castro et al., 2012).

A. ludoviciana subsp. Mexican, Estafiate or Iztauyatl is one of the most popular medicinal plants of Mexican phytotherapy and is used for gastrointestinal pain. Several studies have reported anti-inflammatory, antibacterial and anthelmintic effects (Wright, 2003). The species

A. ludoviciana belongs to the Anthemideae tribe considered as a complex taxon because it includes various varieties. Botanical materials that are sold in Mexican markets are generally considered to include only the "Mexican" subspecies.
This subspecies differs from most of the rest by having a relatively flexible inflorescence and open at least in well-developed plants with elongation of the branches. All subspecies of $A$. ludoviciana are aromatic, perennial and rhizomatous herbs, approximately 30 to $100 \mathrm{~cm}$ high, white and tomentose above the ground, the flowers are 2.5-5 $\mathrm{mm}$ high.

It is a plant native to areas of pine and oak forest in the highlands of Mexico; It is frequently found as secondary vegetation, since it derives from coniferous oak forests or tropical forests and usually penetrates some grassland scrublands, so it is considered as grass, but today it can be found more frequently in the courtyards of houses and gardens (Rocha, 2000). Its leaves are velvety in appearance, pinnatisectas, have between 5 and 7 lobes with a deep incision; They are serrated dark green with no hair on the top, and on the underside they are raised and velvety. Its flowers are brown-yellowish or purple with a bitter taste with a characteristic aromatic smell when squeezed (Rzedowski and Rzedowski, 2001).

In general, the species of the genus Artemisia have been studied for their benefits and pharmacological, antibacterial, antiparasitic, antimalarial, antihepatotoxic, antifungal and antioxidant properties. In the particular case of A. ludoviciana subsp. Mexican is used as an anthelmintic, antibacterial and traditional uses to relieve stomach pain (Olivas, 1999). The pharmacological action of this plant has had an effect against biological models.

There have been multiple studies that demonstrate the antimicrobial effect of $\mathrm{A}$. ludoviciana, which validates the traditional uses widely spread in traditional medicine of the peoples and communities of various parts of the country.

Castillo-Juárez et al. (2009), performed the exploration of plants recognized for their antibacterial potential. They made aqueous and methanolic extracts from various parts of the plants. Derived from this study it was found that A. ludoviciana subsp. Mexican presented the best antibacterial activity against Helycobacter pylori, which showed sensitivity to the aqueous extract at a minimum inhibitory concentration (MIC) of $125 \mu \mathrm{g} / \mathrm{mL}$. 
In this same context Borja (2013) and Cortés (2012), performed the fractionation of the aqueous extract using organic solvents of different polarity. The biodirected study against $\mathrm{H}$. pylori showed that the dichloromethane fraction exerts the best antibacterial effect at an MIC of $31.2 \mu \mathrm{g} / \mathrm{mL}$. The analysis of the fraction showed the presence of stafiatine, a sesquiterpene lactone effective for its antimicrobial effects. These studies show that organic fractions have a better antimicrobial effect than crude extracts, at least against $\mathrm{H}$. pylori (Castillo-Juárez et al., 2009; Cortés, 2012; Borja, 2013).

With regard to activity against enterobacteria, it has been observed that the crude extracts of A. ludoviciana subsp. Mexican obtained with methanol exert antibacterial activity against $E$. coli and Shigella flexnery-2, at a MIC of $8000 \mu \mathrm{g} / \mathrm{mL}$ or slightly lower for both bacteria (Analís et al., 2005). On the other hand, the crude ethanolic extracts of A. ludoviciana indicate antibacterial activity against Vibrio cholerae 01 and V. cholerae 0139 at an MIC of 4000 and $6000 \mu \mathrm{g} / \mathrm{mL}$, respectively (García et al., 2006). In addition, V. cholerae enterotoxin production is 50\% inhibited for serotype 01 , while for serotype $013975 \%$ of said production is inhibited (García et al., 2006). In general, studies of antimicrobial activity of A. ludoviciana against enterobacteria show that large amounts of crude extract are required to achieve MIC and inhibit the development of bacteria.

Although the antimicrobial potential of crude extracts of A. ludoviciana has been demonstrated, it is not known whether organic fractions exert better effects against enterobacteria. In the same way it is unknown how the extracts of this plant affect the kinetics of bacterial growth. Therefore, in this work the antimicrobial effect of organic fractions of $A$. ludoviciana subsp. Mexican vs. Enterobacteria.

\section{Methodology to be developed}

\section{Collection of plant material}

The plant was collected in the ejido El Abra, municipality of Ciudad Valles, S. L. P., at Km 12 of Highway No. 70, Cd. Valles-Tampico. The coordinates of the collection site are $+21^{\circ} 58$ '27.105 "North latitude and + $98^{\circ} 54$ ' 47.6604" East longitude.

\section{Preparation of plant material}

For the preparation of organic extracts, the leaves were dried in the shade, sheltered from dust and direct solar radiation, spreading the leaves on brown paper on a clean and dry surface for 1 week. To complete the drying process, the leaves were taken to an oven at a temperature of $45^{\circ} \mathrm{C}$ for a period of 2 days (Ara, 2006). After the drying period, the leaves were crushed in an Oster blender, until a fine powder was obtained, which was stored in a brown bag to protect it from light and avoid degrading some photosensitive compounds. To obtain the essential oil, fresh leaves washed superficially with running water were used. $50 \mathrm{~g}$ portions of leaf were used for the extraction process.

\section{Preparation and obtaining of the extracts}

The extracts were obtained from the ground plant material, by means of maceration techniques, using organic solvents of increasing polarity; while distilled water was used for the aqueous extract. Based on the increasing polarity of the solvents, hexane (Hex), dichloromethane $(\mathrm{CH} 2 \mathrm{Cl} 2)$, ethanol $(\mathrm{EtOH})$, methanol $(\mathrm{MeOH})$ and water were used, useful for fractional extraction from non-polar compounds, compounds with intermediate polarity to polar compounds In addition, the extraction of essential oils was carried out (Cos et al., 2006; Ringuelet and Piña, 2013).

\section{Extract Concentration}

The extracts obtained were filtered and concentrated under reduced pressure on a rotary evaporator (Büchi) until the dry extract was obtained. The extract obtained was resuspended in $20 \mathrm{~mL}$ DMSO (Dimethylsulfoxide) to solubilize and release the extract that was adhered to the flask walls, homogenizing with rotary movements and removing the extract that had been generated. Weights of the empty flask and flask with extract were recorded to calculate the concentration of each extract by weight difference. 


\section{Preliminary phytochemical analysis of the extracts of A. ludoviciana subsp. Mexican}

To determine the compounds present in the plant, the analysis of the fractions and extracts obtained from the leaves of A. ludoviciana subsp. Mexican Qualitative reactions proposed in the phytochemical gait methodology were mounted. The presence of reducing sugars, flavonoids, polyphenols, coumarins, cardiotonic glycosides, sesquiterpenic lactones, saponins and alkaloids was evaluated with specific tests that reveal each type of secondary metabolite (Lock, 1994).

\section{Determination of antimicrobial activity}

For the trials, E. coli strains ATCC25922, Salmonella typhi ATCC 14028 and Klebsiella pneumoniae ATCC 31488 were used. The strains were activated in $5 \mathrm{~mL}$ of nutrient broth and incubated at $37^{\circ} \mathrm{C}$ for $24 \mathrm{~h}$ in a digital tabletop incubator ( IKA, KS4000). Biochemical tests were performed to confirm the identity of the bacteria. They were subsequently seeded in MacConkey agar and kept refrigerated until use.

\section{Inoculum preparation}

Two bacterial colonies were inoculated in nutrient broth and incubated at $37^{\circ} \mathrm{C}$ at $140 \mathrm{rpm}$ for 12 to 16 hours until reaching the logarithmic stage of the bacterial growth curve. After the incubation period, the bacterial density was determined at a wavelength of $600 \mathrm{~nm}$ in a spectrophotometer (Genesys 20) From the initial culture a bacterial suspension was made, adjusting the turbidity with sterile distilled water until obtaining an optical density of 0.08 at 0.1 to $600 \mathrm{~nm}$, equivalent to McFarland Standard 0.5 (1.5 x $108 \mathrm{CFU} / \mathrm{mL}$ ) (Anon, 2003).

\section{6-well plate microdilution test}

The tests were performed on 96-well flat bottom polystyrene plates. The fractions and extracts of known concentration were diluted with nutrient broth in a 1: 2 ratio, to obtain decreasing concentrations of the extracts in a final volume of $150 \mu 1$ in each well. Each well was inoculated with $15 \mu \mathrm{l}$ with the bacteria to be tested at a concentration of $1 \times 10^{5} \mathrm{UFC} / \mathrm{mL}$.
The plates were incubated at $37 \pm 2{ }^{\circ} \mathrm{C}$ with shaking at $180 \mathrm{rpm}$; absorbance readings at a wavelength of $620 \mathrm{~nm}$ were taken every $2 \mathrm{~h}$ in a microplate spectrophotometer (Beckman Culter, DTX 800) (Stella and Marín, 2009). As controls, nutrient broth measurements (culture medium blank), growth in nutrient broth without extract (white), growth in nutrient broth with DMSO (negative control) were performed. Three repetitions of each dilution (technical replicas) and two biological replicas of the tests were performed. The values obtained from the absorbance measurements were averaged, the average of 3 repetitions was plotted against the incubation time. The minimum inhibitory concentration (MIC) was determined as the concentration where no bacterial growth was observed (Stella and Marín, 2009)

\section{Results}

For the fractional extraction of the compounds present in the leaves of A. ludoviciana subsp. Mexican organic extracts were obtained. Hexane (Hex) was used to separate non-polar compounds, dichloromethane $\left(\mathrm{CH}_{2} \mathrm{Cl}_{2}\right)$ to isolate compounds of intermediate polarity and methanol $(\mathrm{MeOH})$ for polar compounds. In addition, two crude extracts, hydroalcoholic and aqueous, were obtained to extract polar compounds present in the leaves. The extracts were concentrated to dryness and resuspended in DMSO, ensuring solubility. The concentrations for each of the organic fractions and the crude extracts are shown in Table 1.

\begin{tabular}{|l|r|}
\hline \multicolumn{1}{|c|}{ Abstract } & Concentration $(\mathbf{m g} / \mathbf{m L})$ \\
\hline Hexane & 103.04 \\
\hline Dichloromethane & 79.83 \\
\hline Methanolic & 102.00 \\
\hline Hydroalcoholic & 77.700 \\
\hline Aqueous & 495.00 \\
\hline
\end{tabular}

Table 1 Concentration of the fractions and extracts obtained from A. ludoviciana subsp. Mexican

\section{Phytochemical analysis of the extracts of $A$. ludoviciana subsp. mexican}

To determine the compounds present in each of the organic fractions and in the raw extracts of the leaves of $A$. ludoviciana subsp. Mexican qualitative analyzes were performed using the reactions proposed in the phytochemical march. 
The results for functional groups and secondary metabolites showed the presence of various compounds such as tannins, saponins, polyphenols and lactone-type constituents (terpenic, coumarins and cardiotonic compounds) for crude fractions and extracts. All extracts, both fractions and crudes, coincide with the presence of triterpenes and steroids for the Liberman Buchard test; polyphenols with the Salkowski test. The presence of compounds with lactonic rings was validated by tests with sodium hydroxide and the Baljet test, while the presence of coumarins was revealed with the Erlich test.

On the other hand, weak reactions for alkaloids were obtained, which can be attributed to the low concentration of these metabolites in the leaves of A. ludoviciana subsp. Mexican These results coincide with those reported in other plants of the same genus and family. In A. annua, polyphenols and flavonoids have been identified by the method of Geissman and Shinda (Bucciarelli et al., 2007); in addition to reducing sugars, flavonoids, alkaloids, triterpenes, steroids, phenols and tannins (Acosta et al., 2012). In A. absinthium L. the presence of reducing sugars, lactonic compounds, phenols, amines, quinones, triterpenes, steroids, alkaloids, flavonoids, leucoanthocyanidins and bitter principles has been demonstrated (Guerra et al., 2001).

The results obtained for $A$. ludoviciana subsp. Mexican, are similar to those previously reported for other species of the same genus, which demonstrates the kinship and evolutionary relationships between these species.

Chemical tests show an overview of the metabolites present in the leaves of $A$. ludoviciana subsp. Mexican, indicating that it synthesizes a great variety of compounds, which may be responsible for the biological effects attributed to this plant. More than one test was performed for the same group of compounds, which were carried out in duplicate to ensure the fidelity of the results.

\section{Antimicrobial activity against enterobacteria}

To determine the antimicrobial effect, the bacteria were grown in nutrient broth (white), nutrient broth with DMSO (negative control) and in the presence of fractions and crude extracts.
Growth curves were plotted for each bacterium under the mentioned conditions. The well with the lowest concentration of extract where no bacterial development was observed was considered as the MIC. The data obtained from the growth curves were normalized according to the maximum growth obtained for the strain in nutrient broth. With the bacterial growth curves the value of the slope "m" was determined which is related to the time of generation of the bacterium.

\section{Effect against Escherichia coli}

Table 2 shows the MIC of each fraction and / or extracts against $E$. coli, as well as the slope values in each condition. When the bacteria grow under normal conditions, nutritive broth (control), the value of $\mathrm{m}=0.09334 \pm 0.002$, while in the presence of DMSO $\mathrm{m}=0.09216 \pm$ 0.003 . These values are similar, in the blank and in the control, which indicates that the solvent used does not interfere with the development of the bacteria (Figure 1). However, when E. coli grows in culture medium added with the fractions and extracts, the value of $\mathrm{m}$ is affected.

\begin{tabular}{|l|r|r|}
\hline \multicolumn{1}{c}{ Condition } & WCC & m value \\
\hline Nutritious broth & & 0.09334 \\
\hline $5 \%$ DMSO & & 0.09216 \\
\hline $\mathrm{Hex}$ & $4830 \mu \mathrm{g} / \mathrm{mL}$ & 0.00200 \\
\hline $\mathrm{CH}_{2} \mathrm{Cl}_{2}$ & $374.2 \mu \mathrm{g} / \mathrm{mL}$ & 0.00050 \\
\hline $\mathrm{MeOH}$ & $478.1 \mu \mathrm{g} / \mathrm{mL}$ & 0.00000 \\
\hline EtOH & $364.2 \mu \mathrm{g} / \mathrm{mL}$ & 0.00200 \\
\hline Ac & $2320.0 \mu \mathrm{g} / \mathrm{mL}$ & 0.00200 \\
\hline Ace & $2.5 \%$ & 0.00200 \\
\hline
\end{tabular}

Table 2 Minimum inhibitory concentration and $\mathrm{m}$ value for E. coli

Bacterial growth curves show the development of $E$. coli over a period of 12 hours. The adaptation phase or lag phase is a short stage that lasts 2 hours, which is followed by an exponential phase of 8 hours, while the idiophase is observed until 12 hours. This growth pattern was observed when the bacterium grows in nutrient broth (white) and in nutrient broth plus DMSO (negative control), indicating that the presence of the solvent does not affect the growth of $E$. coli. However, when the bacteria grow in the presence of organic fractions and raw extracts, the growth curve is maintained in the lag phase during the 12 hours of the test (Figure 1 and 2). 
The results obtained show that the organic fractions and extracts of the leaves of $A$. ludoviciana subsp. Mexican inhibit microbial development. The MIC is the dose of extract at which no microbial growth was observed.

The growth obtained from $E$. coli in nutrient broth with DMSO is similar to that obtained in the white culture, which demonstrates that the solvent used does not affect the development of the bacteria, attributing the effect to the bioactive compounds present in the organic fractions. E. coli is more sensitive to the fraction $\mathrm{CH}_{2} \mathrm{Cl}_{2}$ (CMI 374.2 $\mu \mathrm{g} / \mathrm{mL}$ ) that to the fractions $\mathrm{MeOH}$ (CMI 478.1 $\mu \mathrm{g} / \mathrm{mL})$ and hex (CMI $483.0 \mu \mathrm{g} / \mathrm{mL})$; which indicates that in the fraction $\mathrm{CH}_{2} \mathrm{Cl}_{2}$ Bioactive compounds responsible for antimicrobial activity are found in greater proportion (Figure 1). E. coli is more sensitive to the fraction $\mathrm{CH}_{2} \mathrm{Cl}_{2}$ (CMI $\left.374.2 \mu \mathrm{g} / \mathrm{mL}\right)$ that to the fractions $\mathrm{MeOH}(\mathrm{CMI} 478.1 \mu \mathrm{g} / \mathrm{mL})$ and Hex (CMI 483.0 $\mu \mathrm{g} / \mathrm{mL})$; which indicates that in the fraction $\mathrm{CH}_{2} \mathrm{Cl}_{2}$ Bioactive compounds responsible for antimicrobial activity are found in greater proportion (Figure 1).

These results suggest that the compounds responsible for the antibacterial effect have intermediate polarity. Regarding the effect of raw extracts, it was found that the extract $\mathrm{EtOH}$ (CMI $364.2 \mu \mathrm{g} / \mathrm{mL}$ ) is more active than the extract Ac (CMI $2320.0 \mu \mathrm{g} / \mathrm{mL}$ ). The MIC of both extracts for $E$. coli is lower than previously reported by Analís et al. (2005) with a crude $\mathrm{MeOH}$ extract with an MIC $8000 \mu \mathrm{g} / \mathrm{mL}$ for $E$. coli.

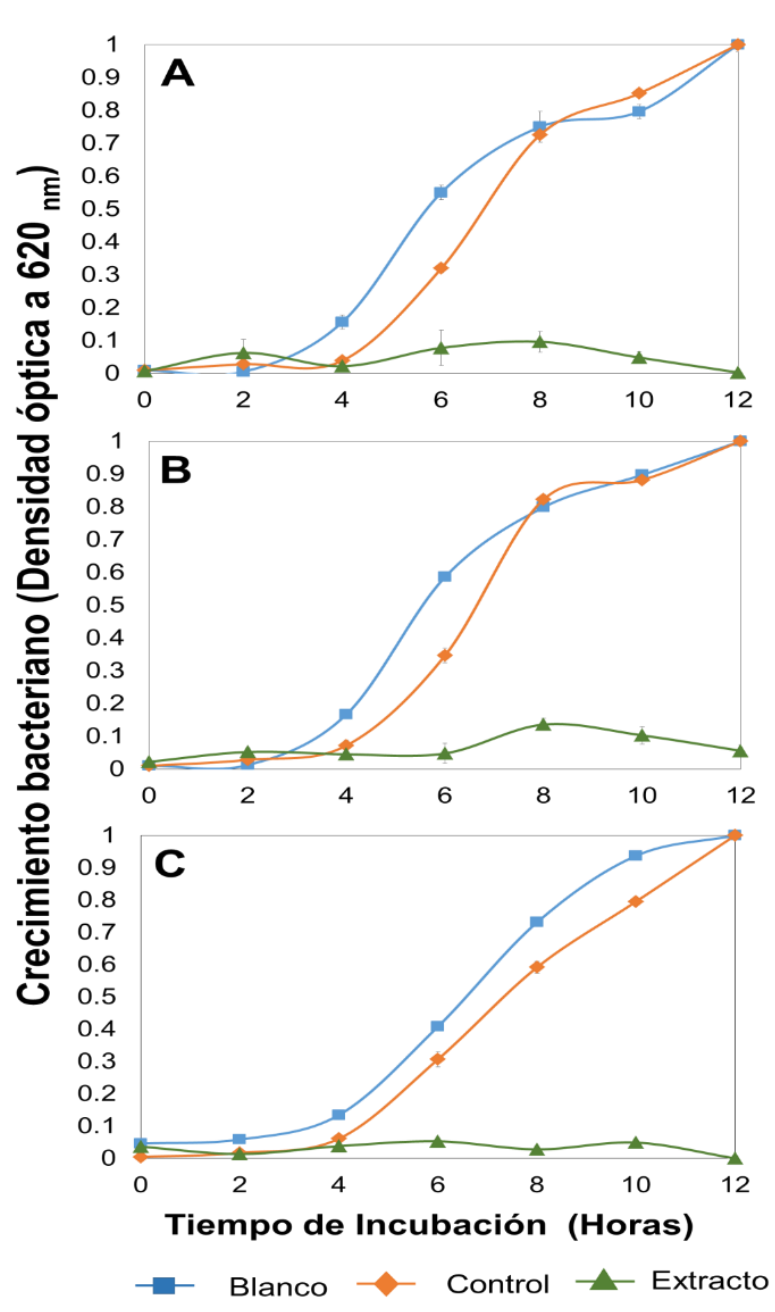

Figure 1 Effect of organic fractions on the bacterial growth curve of E. coli. The squares represent the growth of E. coli in nutritious broth (white); rhombuses the growth of the bacteria with DMSO (negative control); the triangles show the growth in nutritious broth with organic fractions. WCC A) $483 \mu \mathrm{g} / \mathrm{mL}$ of the Hex fraction, B) $374.2 \mu \mathrm{g} / \mathrm{mL}$ of the $\mathrm{CH} 2 \mathrm{Cl} 2$ fraction, C) $478.1 \mu \mathrm{g} / \mathrm{mL}$ of the $\mathrm{MEOH}$ fraction. 


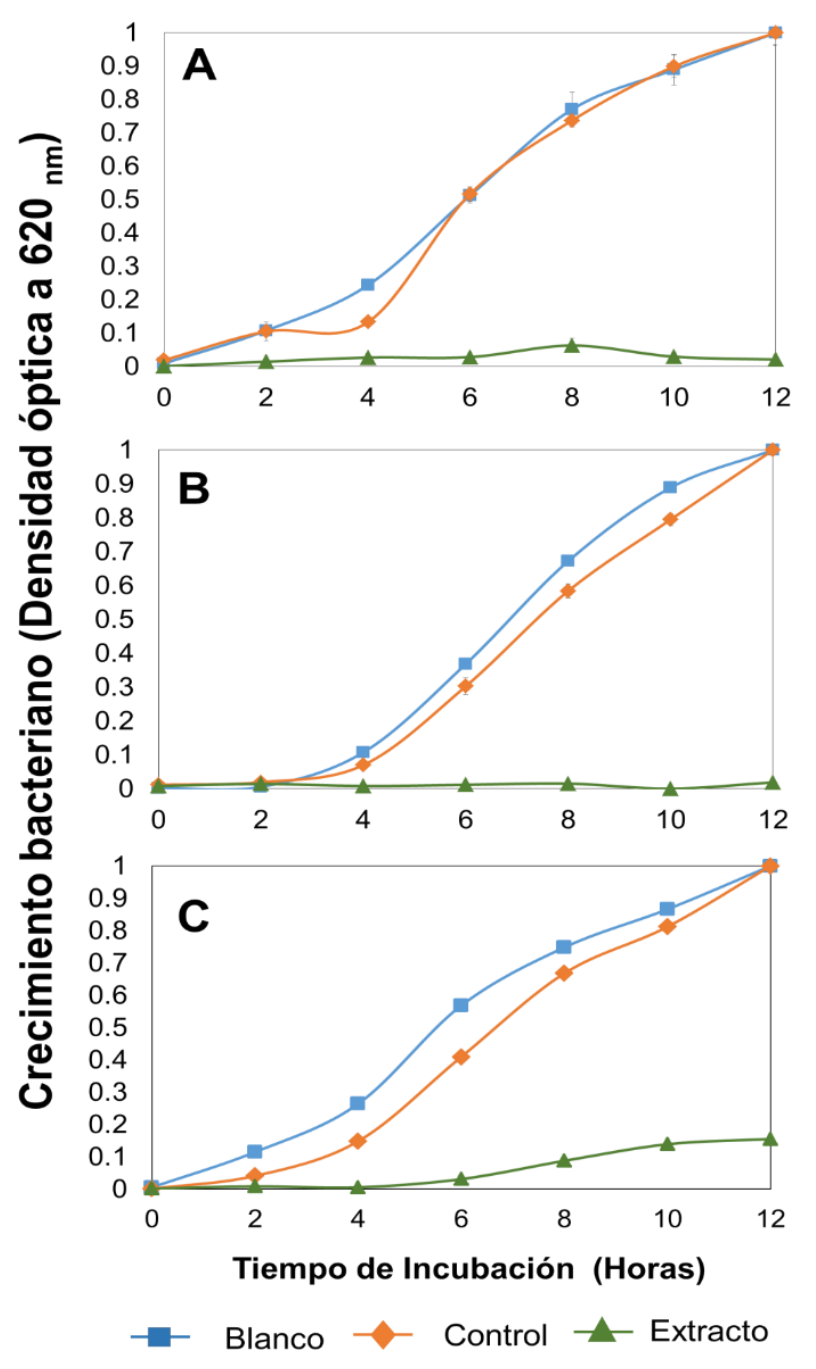

Figure 2 Effect of extracts and essential oil on the bacterial growth curve of E. coli. The squares represent the growth of E. coli in nutritious broth (white); rhombuses the growth of the bacteria with DMSO (negative control); the triangles show the growth in nutritious broth with the extracts. MIC of A) $364.2 \mu \mathrm{g} / \mathrm{mL}$ of the hydroalcoholic extract, B) $2320.0 \mu \mathrm{g} / \mathrm{mL}$ of the aqueous extract, C) $2.5 \%$ of the essential oil

In addition, the results demonstrate that the organic fractions exert a better effect than the crude extract Ac, with MIC values lower than $500 \mu \mathrm{g} / \mathrm{mL}$. The crude extract with EtOH turned out to be more active than the organic fractions and than the Ac extract. This effect can be attributed to the fact that fresh vegetable material was used in its preparation, which prevented the loss of volatile compounds compared to the fractions where dry leaves were used, some terpenic compounds that could participate in the antimicrobial activity were probably lost. The sensitivity of E. coli from highest to lowest was: EtOH Extract> $\mathrm{CH} 2 \mathrm{Cl} 2$ Fraction> MeOH Fraction> Hex Fraction> Ac Extract; showing that the leaves of A. ludovicina subsp. Mexican exercise antimicrobial activity against $E$. coli.
Regarding the essential oil, the WCC for E. coli was $2.5 \%$, obtained from serial dilutions of a $40 \%$ solution of essential oils. It was determined that the oil at the concentration of $2.5 \%$ exerts an inhibitory effect. These results show that essential oils exert antibacterial effect at low concentration, causing the same effect of fractions and leaf extracts.

\section{Efecto contra S. typhi}

Table 3 shows the MIC of each fraction and / or extracts against $S$. typhi. Similar values of $\mathrm{m}$ were obtained, in nutrient broth (white) $\mathrm{m}=$ $0.09937 \pm 0.004$; while in the presence of DMSO (negative control) $\mathrm{m}=0.09737 \pm 0.001$. This indicates that DMSO does not exert negative effects on bacterial replication (Figure 3 and 4). However, with the presence of fractions and extracts, the value of $m$ decreases dramatically indicating that these extracts inhibit the replication of S. typhi (Table 3).

\begin{tabular}{|c|c|c|}
\hline Condition & WCC & m value \\
\hline Nutritious broth & & 0.09937 \\
\hline DMSO $5 \%$ & & 0.09737 \\
\hline Hex & $4830 \mu \mathrm{g} / \mathrm{mL}$ & 0.00290 \\
\hline $\mathrm{CH}_{2} \mathrm{Cl}_{2}$ & $374.2 \mu \mathrm{g} / \mathrm{mL}$ & 0.00350 \\
\hline $\mathrm{MeOH}$ & $478.1 \mu \mathrm{g} / \mathrm{mL}$ & 0.00130 \\
\hline $\mathrm{EtOH}$ & $364.2 \mu \mathrm{g} / \mathrm{mL}$ & 0.00010 \\
\hline Ac & $2320.0 \mu \mathrm{g} / \mathrm{mL}$ & 0.00200 \\
\hline Ace & $2.5 \%$ & 0.00200 \\
\hline
\end{tabular}

Table 3 Minimum inhibitory concentration and $\mathrm{m}$ value for S.typhi

Bacterial growth curves show the development of the bacteria over a period of 12 hours. The lag phase is a stage that lasts 4 hours, followed by the exponential phase of 4 hours, the idiophase is observed until 9 hours and the stationary phase after 10 hours. The growth pattern is similar in nutrient broth (white) and in nutrient broth plus DMSO (negative control), which indicates that the presence of DMSO does not affect the growth of $S$. typhi. However, with organic fractions and raw extracts, the growth curve is maintained in the lag phase during the 12 hours of the test (Figure 3 and 4).

These results show that fractions, extracts and essential oil inhibit microbial development. The sensitivity of $S$. typhi from highest to lowest: EtOH Extract> $\mathrm{CH} 2 \mathrm{Cl} 2$ Fraction> MeOH Fraction> Hex Fraction> Ac Extract. 
The MIC of the essential oil against $S$. typhi was $2.5 \%$. The essential oil exerts an inhibitory effect by the extraction of non-polar compounds and compounds of intermediate polarity, without the presence of non-volatile metabolites, pigments, chlorophyll, etc.

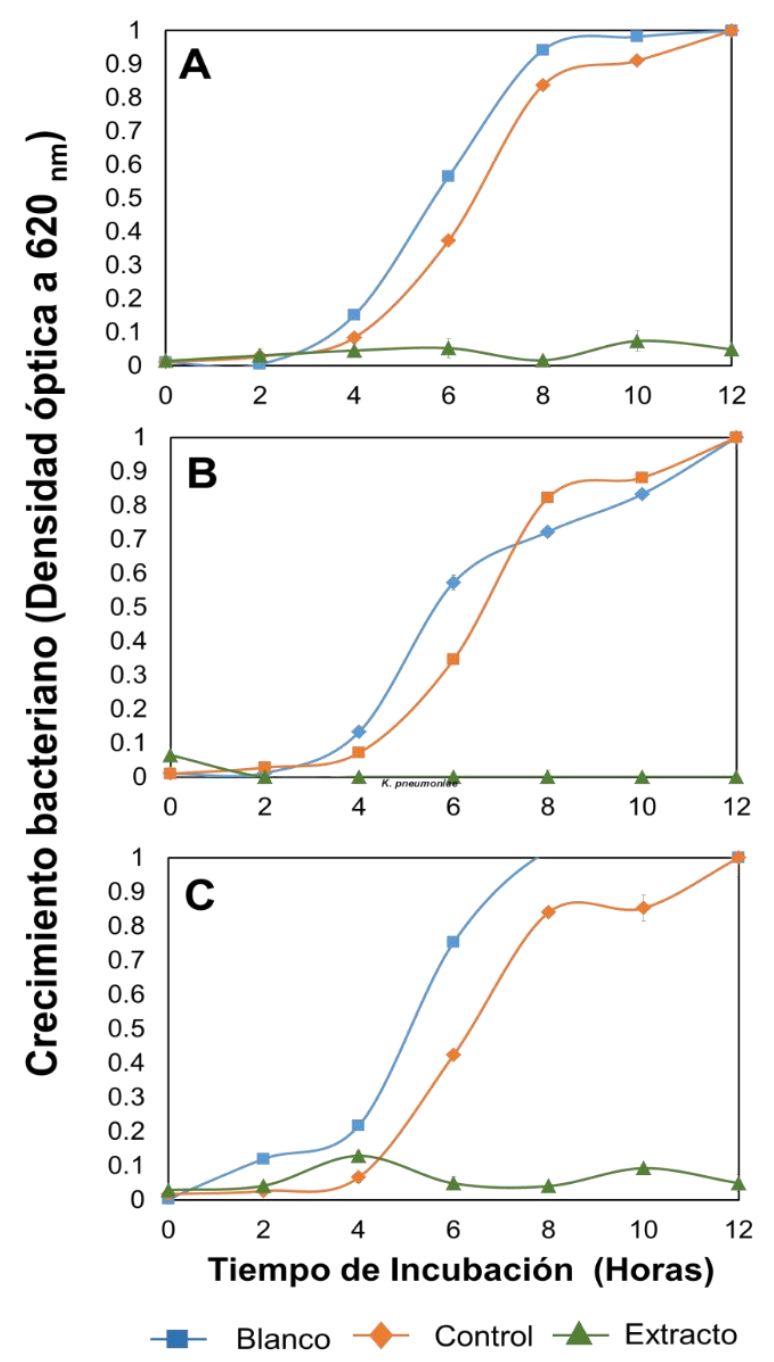

Figure 3 Effect of organic fractions on the bacterial growth curve of $\mathrm{S}$. typhi. The squares represent the growth of S. typhi in nutritious broth (white); rhombuses the growth of the bacteria with DMSO (negative control); the triangles show the growth in nutritious broth with organic fractions. A) MIC A483 $0 \mu \mathrm{g} / \mathrm{mL}$ of the Hex fraction, B) $374.2 \mu \mathrm{g} / \mathrm{mL}$ of the $\mathrm{CH} 2 \mathrm{Cl} 2$ fraction, C) $478.1 \mu \mathrm{g} / \mathrm{mL}$ of the MEOH fraction

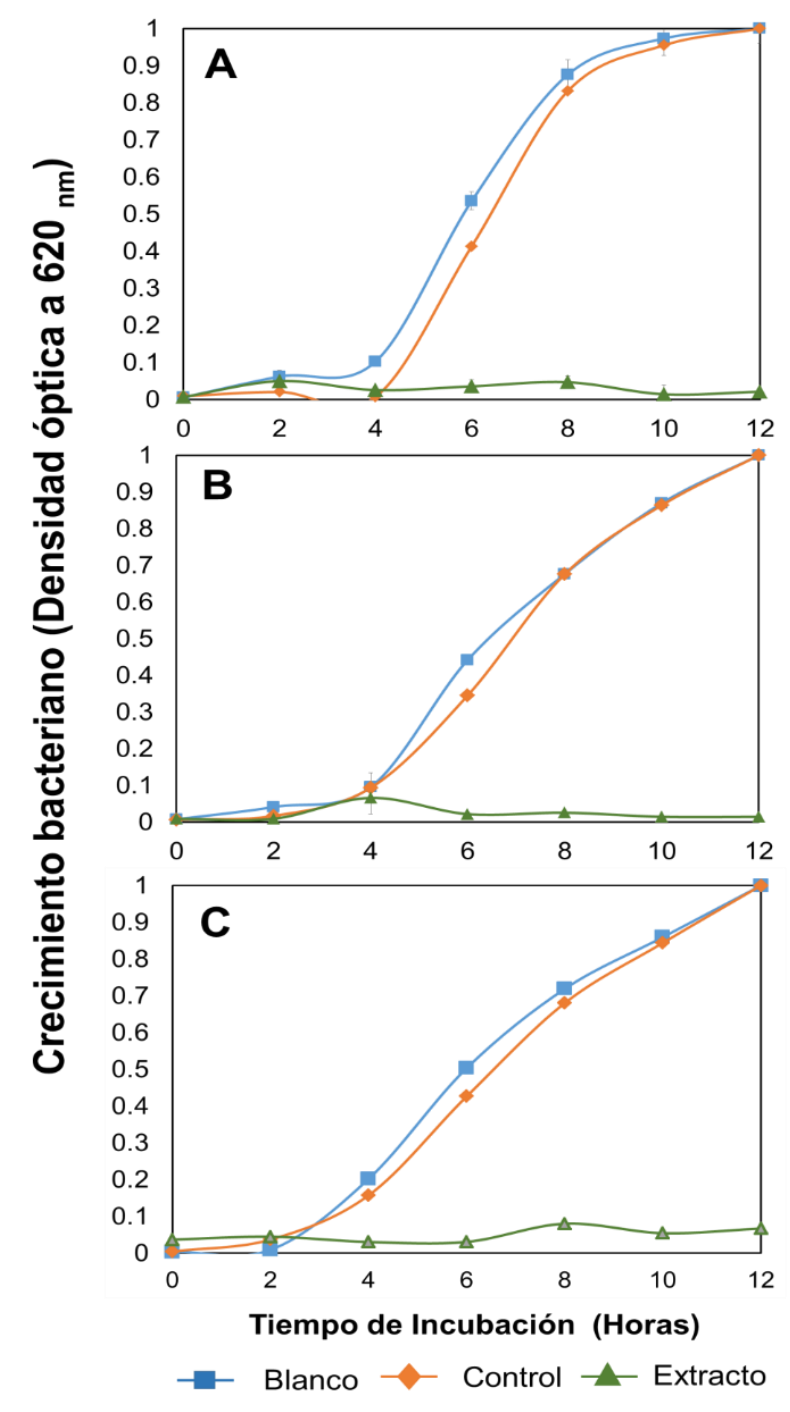

Figure 4 Effect of extracts and essential oil on the bacterial growth curve of S. typhi. The squares represent the growth of $\mathrm{S}$. typhi in nutritious broth (white); rhombuses the growth of the bacteria with DMSO (negative control); the triangles show the growth in nutritious broth with the extracts. MIC of A) $364.2 \mu \mathrm{g} /$ $\mathrm{mL}$ of the hydroalcoholic extract, B) $2320.0 \mu \mathrm{g} / \mathrm{mL}$ of the aqueous extract, C) $2.5 \%$ of the essential oil.

\section{Effect against K. pneumoniae}

Table 4 shows the MIC of each fraction and / or extracts against $\mathrm{K}$. pneumoniae. When the bacteria grow under normal conditions, nutrient broth (white), the value of $m=0.09524 \pm 0.003$, while in the presence of DMSO $\mathrm{m}=0.09666 \pm$ 0.001 , the values obtained for $\mathrm{m}$ are similar, indicating that the solvent used for the solvation of organic fractions and extracts does not exert negative effects on the replication of the bacteria (Figure 9 and 10). However, when the bacterium grows in the presence of fractions and extracts, the value of $m$ decreases dramatically indicating that these extracts inhibit bacterial replication. This concentration is considered as MIC, because no microbial development was observed.

HERNÁNDEZ-MORALES, Alejandro, AVILA-PADRÓN, Francisco Javier, CARRANZA-ÁLVAREZ, Candy and MALDONADOMIRANDA, Juan José. Evaluation of the antibacterial activity of Artemisia ludoviciana subsp. Mexican against three enterobacteria. Journal of Natural and Agricultural Sciences. 2019 
The essential oil concentration for $\mathrm{K}$. pneumoniae was $2.5 \%$. It is known that essential oils contain a large amount of terpenic compounds, so their antibacterial activity stands out. However, comparing the fractions with the oil shows that it also has an antibacterial effect, so the effect attributed to this plant is a synergy of compounds present in the leaves.

\begin{tabular}{|l|r|r|}
\hline \multicolumn{1}{|c|}{ Condition } & WCC & m value \\
\hline Caldo nutritivo & & 0.09524 \\
\hline DMSO 5\% & & 0.09666 \\
\hline $\mathrm{Hex}$ & $4830 \mu \mathrm{g} / \mathrm{mL}$ & 0.00300 \\
\hline $\mathrm{CH}_{2} \mathrm{Cl}_{2}$ & $374.2 \mu \mathrm{g} / \mathrm{mL}$ & 0.00130 \\
\hline $\mathrm{MeOH}$ & $478.1 \mu \mathrm{g} / \mathrm{mL}$ & 0.00710 \\
\hline $\mathrm{EtOH}$ & $364.2 \mu \mathrm{g} / \mathrm{mL}$ & 0.00050 \\
\hline $\mathrm{Ac}$ & $2320.0 \mu \mathrm{g} / \mathrm{mL}$ & 0.00140 \\
\hline $\mathrm{Ace}$ & $2.5 \%$ & 0.00200 \\
\hline
\end{tabular}

Table 4 Minimum inhibitory concentration and $\mathrm{m}$ value for K. pneumoniae

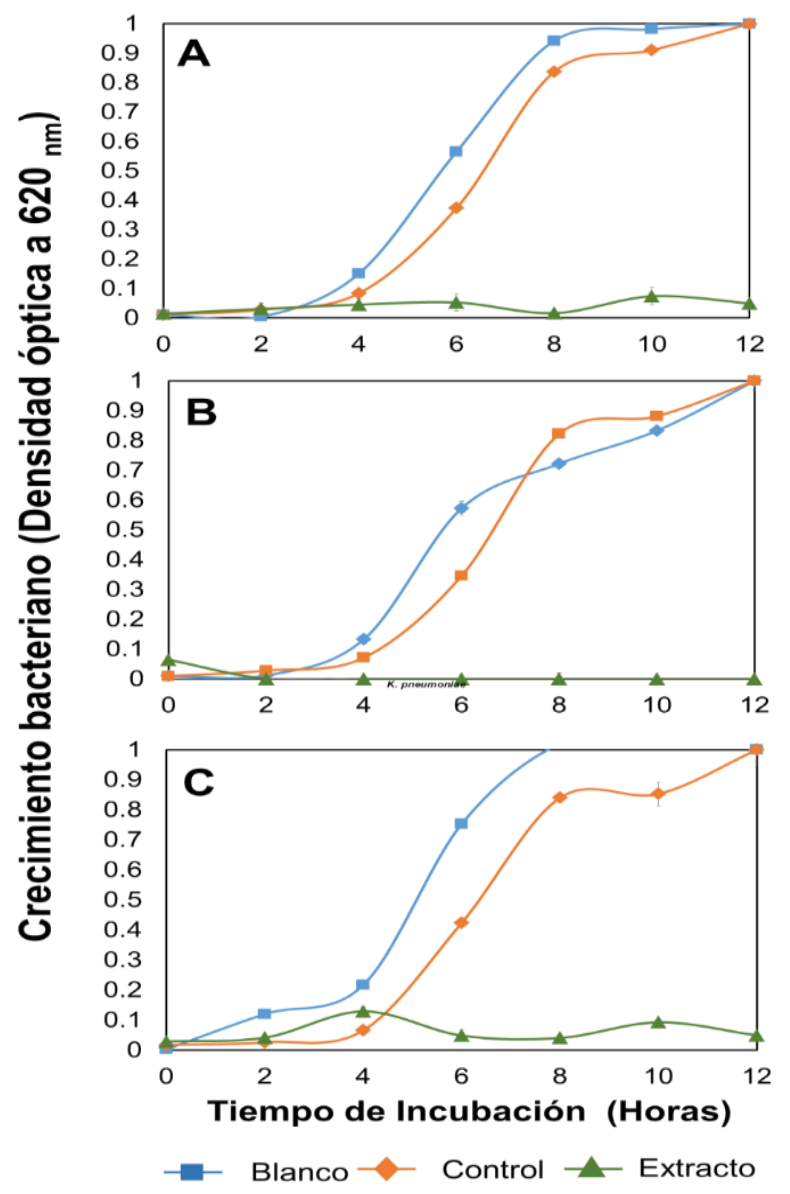

Figure 5 Effect of organic fractions on the bacterial growth curve of K. pneumoniae. The squares represent the growth of K. pneumoniae in nutritious broth (white); rhombuses the growth of the bacteria with DMSO (negative control); the triangles show the growth in nutritious broth with organic fractions. MIC A) $\mu \mathrm{g} / \mathrm{mL}$ of the Hex fraction, B) $374.2 \mu \mathrm{g} / \mathrm{mL}$ of the $\mathrm{CH} 2 \mathrm{Cl} 2$ fraction, C) $478.1 \mu \mathrm{g} / \mathrm{mL}$ of the MEOH fraction
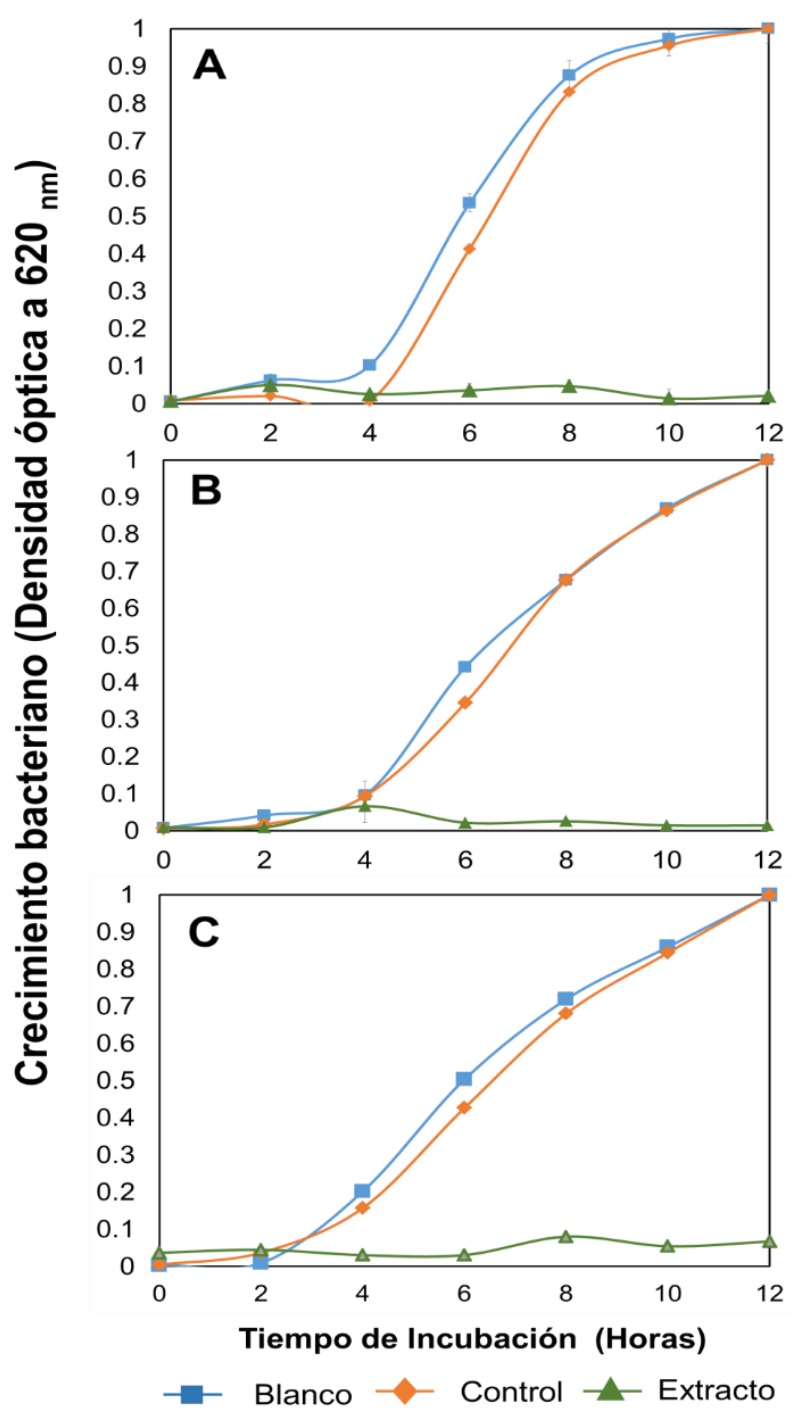

Figure 6 Effect of extracts and essential oil on the bacterial growth curve of K. pneumoniae. The squares represent the growth of K. pneumoniae in nutritious broth (white); rhombuses the growth of the bacteria with DMSO (negative control); the triangles show the growth in nutritious broth with the extracts. MIC of A) $364.2 \mu \mathrm{g} /$ $\mathrm{mL}$ of the hydroalcoholic extract, B) $2320.0 \mu \mathrm{g} / \mathrm{mL}$ of the aqueous extract, C) $2.5 \%$ of the essential oil

To determine the MIC, serial dilutions were made 1: 2, obtaining different doses of the fractions and extracts. For the test DMSO was used as a solvent, which at a concentration of $12.5 \%$ inhibits microbial development. However, at the concentration of $6.25 \%$, used in this study the bacterial growth was not affected (Figures 1-6), attributing the effect to the metabolites present in the fractions and extracts; no to the presence of DMSO in the culture medium.

Different bacterial growth patterns were observed depending on the concentration of the fractions and extracts. Development inhibition was obtained in direct relation to concentration, better effect at higher doses. 
The effect obtained is attributed to the synergistic effect of the blue-violet band with RF 0.717 in synergistic action with the rest of the bands in the fractions and extracts. The best effect corresponds to the $\mathrm{CH} 2 \mathrm{Cl} 2$ fraction at an MIC of $374.2 \mu \mathrm{g} / \mathrm{mL}$, in which the greatest number of bands was observed; followed by the $\mathrm{MeOH}$ fraction with an MIC of $478.10 \mu \mathrm{g} / \mathrm{mL}$, while the Hex fraction at $483.00 \mu \mathrm{g} / \mathrm{mL}$. This could be attributed to the differential solubilization of metabolites in each of the fractions, being optimal in the $\mathrm{CH}_{2} \mathrm{Cl}_{2}$. Regarding the effect of the extracts, the best antimicrobial effect corresponds to the hydroalcoholic extract with an MIC of $364.2 \mu \mathrm{g}$ $/ \mathrm{mL}$, in relation to the aqueous extract (Table 5). With regard to essential oils, for the three enterobacteria, it was observed that at a concentration of $2.5 \%$, it exerts the same antibacterial effect as the fractions and leaf extracts.

\begin{tabular}{|l|r|r|r|r|r|r|}
\hline Bacterium & \multicolumn{3}{c|}{$\begin{array}{c}\text { Organic fraction } \\
\boldsymbol{\mu g} / \mathbf{~ m L}\end{array}$} & \multicolumn{2}{c|}{$\begin{array}{c}\text { Crude extract } \\
\boldsymbol{\mu g} / \mathbf{~ m L}\end{array}$} & \multicolumn{1}{c|}{$\begin{array}{c}\text { Oil } \\
\end{array}$} \\
\cline { 2 - 7 } & $\mathrm{Hex}$ & $\mathrm{CH}_{2} \mathrm{Cl}_{2}$ & $\mathrm{MeOH}$ & $\mathrm{EtOH}$ & Ac & Ace \\
\hline E. coli & 483 & 374 & 478 & 364 & 2320 & 2.5 \\
\hline S. typhi & 483 & 374 & 478 & 364 & 2320 & 2.5 \\
\hline K. pneumoniae & 483 & 374 & 478 & 364 & 2320 & 2.5 \\
\hline
\end{tabular}

Table 5 MIC comparison of the three enterobacteria

This result demonstrates the high antibacterial potential of essential oils of $A$. ludoviciana subsp. Mexican, attributable to the synergistic effect of the constituents. The effect of essential oils is due to the fact that in their composition there are no pigments and / or compounds of high molecular weight, which facilitates the diffusion of oils in the culture medium and allows contact with the bacteria membrane.

The antimicrobial effect of $A$. ludoviciana subsp. Mexican, it is due to the presence of phenols and polyphenols that show different mechanisms of action such as impeding the synthesis of nucleic acids, proteins or the cell wall or altering the bacterial cell membrane (Carrillo et al., 2001; Mongeli and Pomilio, 2002). In addition, in the presence of tannins in polar extracts, $\mathrm{MeOH}$ fraction, $\mathrm{EtOH}$ and $\mathrm{Ac}$ extract, it could explain its antimicrobial effect. It has been shown that the tannins precipitate the proteins, probably in the cytoplasmic membrane, causing the alteration of the permeability of the same and, consequently, the exchange of nutrients and waste, leading to cell death.
Steroidal compounds are believed to interfere with certain processes of vital synthesis in the bacterial cell (Mongeli and Pomilio, 2002; Sáenz, 2004).

Terpenes or terpenoids are active against bacteria, viruses, fungi and protozoa. It is believed that this antimicrobial activity is due to a disturbance of the cell membrane structure due to its lipophilic nature. However, triterpenes have various mechanisms depending on their chemical nature, for example, those of a hydrocarbon nature, usually have a depressing action on surface tension, that is, it alters the selectivity of the cytoplasmic membrane for exchange of substances However, alcoholic triterpenes can alter the colloidal nature of the cell's protoplasm causing death (Mongeli and Pomilio, 2002; Sáenz, 2004).

Like triterpenes, flavonoids and coumarins can act by multiple mechanisms, because the substituent groups that appear attached to their structural nucleus tend to be very varied (Williams and Grayer, 2004). The compounds that were identified in great abundance were flavonoids, triterpenes and / or steroids for all the extracts analyzed, which contributes to the antibacterial activity, also revealing the connection between the activity and its chemical composition.

\section{Conclusions}

The extraction method and the conservation technique are fundamental for the isolation of antibacterial compounds, compared with the concentrations obtained from organic extracts and fractionations.

The fractionation with organic solvents favors a differential extraction of the active compounds, the dichloromethane fraction having the greatest diversity of compounds and a better antimicrobial activity.

The dichloromethane fraction showed the highest number of bands, being the most active against $E$. coli, S. typhi and $\mathrm{K}$. pneumoniae, compared to the methanolic and hexane fractions, which showed less band diversity and less antibacterial effect. The antimicrobial activity of A. ludoviciana subsp. Mexican is attributed to a synergistic effect of essential oils and compounds present in the leaves. 


\section{References}

Acosta de la Luz, L., Carballo Guerra, C., Ramos R. (2012). Control de calidad de drogas vegetales: lavado y desinfección de Artemisia annua L. y Tagetes lucida Cav. Revista Cubana Plantas Medicinales, 17, 1.

Alonso-Castro, A. J., Maldonado M., J. J., Zarate, M. A., Jacobo S., M. R., Fernández, G. C. Figueroa Z., L. F., Ríos R., N. A., De León R., M. A., Medellín C., N. A., Reyes M., A., Méndez M., R., Carranza A., C. (2012). Medicinal Plants used in the Huasteca Potosina, México. Journal of Ethnopharmacology, 143(1):292-8.

Analís, A. D., Calzada, F., Cervantes, J. A., Torres, J. Ceballos, G. M. (2005). Antibacterial properties of some plants used in Mexican traditional medicine for the treatment of gastrointestinal disorders. Journal of Ethnopharmacology, 100:153-157.

Anon (2003). Determination of minimum inhibitory concentration (MICs) of antibacterial agents by broth dilution. Clinical Microbiology and Infection, 9, 1.

Ara, R. A. (2006). 40 plantas medicinales. Madrid, España: Edaf.

Borja, R. E. B. (2013). Compuestos AntiHelicobacter pylori y gastroprotectores de la fracción acetato de etilo del extracto acuoso Artemisia ludoviciana subsp. mexicana. UNAM. México, D.F.

Bucciarelli, A., Mancini, M., Skliar, M. (2007). Propiedades gastroprotectoras de plantas medicinales: estudios fitoquímicos y farmacológicos. Revista de la Asociación Médica de Bahía Blanca, 17(1):39

Caniato, R., Puricelli, L. (2001). Review: Natural antimalarial agents (1995-2001). Critical Reviews in plant Sciences, 22 (1): 79105.

Carrillo, A., Brió, S., Quindós, G. (2001). Una nueva generación de fármacos antifúngicos. Revista Iberoamerica Micología, 18:2-5.
Castillo-Juarez, I., González, V., Jaime-Aguilar, H., Martínez, G., Linares, E., Bye, R., Romero (2009). Anti-Helicobacter pylori activity of plants used in mexican traditional medicine for gastrointestinal disorders. Journal of Ethnopharmacology, 122:402-205.

Cortes, A. A. (2012). Estudio del efecto AntiHelicobacter pylori del extracto acuoso de Artemisia ludoviciana subsp. mexicana. UNAM. México, D.F.

Cos, P.; Vlietinck, A. J., Vanden B. D., Maes, L. (2006). Antiinfective potential of natural products: How to develop a stronger in vitro "proof-of-concept". Journal of Ethnopharmacology, 106 (3), 290-302.

Diéguez, R., Rivas Y., Prieto, S., Garrido, G., Agüero, J., Molina-Torres, J. (2004). Potencialidad del género Zanthoxylum como fuente de agentes con actividad biológica. Acta Farm. Bonaerense 23 (2) 243-51.

Dixon, R. A. (1986). Isolation and maintenance of callus and cell suspension cultures in: Plant Cell Culture a Practical Approach. IRL Press, Oxford pp 1-20.

García, L.C., Martínez, R. A, Ortega, S. J. L., Castro, B. F. (2006). Componentes químicos y su relación con las actividades biológicas de algunos extractos vegetales. México, D.F.: Química VIVA.

Guerra, O. M., Torres, I. D. y Martínez, P. L. (2001). Validación del uso tradicional de plantas medicinales cultivadas en Cuba. Revista Cubana Plantas Medicinales, 2, 48-51.

Lock de Ugaz, O. (1994). Investigación Fitoquímica, Métodos en el estudio de productos naturales. Perú: Fondo Editorial de la Pontifiicia Universidad Católica del Perú.

Mongeli, E., Pomilio, A. (2002). Nuevos Medicamentos y etnomedicina del uso popular a la industria. Revista de divulgación científica y tecnología de la asociación ciencia hoy, 12: 2-3. Olivas, S. M. P. (2009). Plantas Medicinales del estado de Chihuahua. Ciudad Juárez, Chihuahua: Universidad Autónoma de Ciudad Juárez. 
Ringuelet, J. A. Piña, S. (2013). Productos naturales vegetales. Buenos Aires: editorial de la Universidad de La plata.

Rocha, A. (2000). Nadie es ombligo en la tierra. México, D.F.: Fundación Teletón.

Rzedowski, G. C., Rzedowski., J. (2001). Flora fanerogámica del Valle de México. 2a. ed., Instituto de Ecología, A. C. y Comisión Nacional para el Conocimiento y Uso de la Biodiversidad, Pátzcuaro (Michoacán).

Sáenz, D. (2003). Medicamentos, plantas medicinales. Fármacos.16 (1 y 2): 13-18.

Sarukhan, J. (1995). Diversidad biológica, Universidad de México 536:3-10.

Stella R. L. Marín C. D. (2009). Metodologías para evaluar in vitro la actividad antibacterial de compuestos de origen vegetal; Scientia et Technica, Universidad Tecnológica de Pereira. Williams, C.A. Grayer, R.J. (2004). Anthocyanins and other flavonoids. Nat. Prod. Rep. 21: 539-573.

Wright, C. W. (2003). Artemisia. USA: CRC Press.

\section{Acknowledgments}

To the UASLP Research Support Fund 2019, agreement number C19-FAI-05-40.40 for support for the realization of this research project. 